J. Clin. Chem. Clin. Biochem.

Vol. 14, 1976, pp. 239-244

\title{
An Improved Method for the Determination of Creatine Kinase Activity in Serum
}

\author{
By D. Stolle and W. Rick
}

Institut für Klinische Chemie und Laboratoriumsdiagnostik der Universität Düsseldorf

(Received January 7/March 10, 1976)

Summary: An improved method for the determination of creatine kinase activity (EC 2.7.3.2) is described. For the reactivation of creatine kinase, serum is first preincubated in the test solution in the presence of dithioerythritol. Then the enzymatic reaction is started by adding creatine phosphate. By optimizing the concentrations in the test solution and by altering the measurement procedure using dithioerythritol as reactivator, the assay is made more sensitive, and a far higher enzyme activity in serum is measured in comparison with other recommended tests. The reaction rate is linear for ten minutes up to $700 \mathrm{U} / 1$. An increase in activity by enzyme dilution was not observed. In this study a sensitivity of detection of $0.9 \mathrm{U} / \mathrm{l}$ was achieved. This would be especially advantageous in the detection of the isoenzymes of creatine kinase after chromatography. Within-run precision was $1.2 \%(\mathrm{CV})$, day-to-day precision was $2.0 \%(\mathrm{CV})$. The test solution is stable for at least 24 hours.

\section{Eine verbesserte Methode zur Bestimmung der Creatinkinase-Aktivität im Serum}

Zusammenfassung: Es wird eine verbesserte Methode für die Aktivitätsmessung der Creatinkinase (EC 2.7.3.2) im Serum beschrieben. Zur Reaktivierung der Creatinkinase wird Serum zunächst im Testansatz mit Dithioerythrit vorinkubiert. Dann erfolgt der Start der enzymatischen Reaktion durch Zugabe von Creatinphosphat. Durch Optimierung der Konzentrationen im Testansatz, durch Änderung der Meßanordnung und mit Dithioerythrit als Reaktivator wird der Test empfindlicher. Im Vergleich mit anderen empfohlenen Tests wird eine weit höhere Enzymaktivitặt im Serum gemessen. Die Zeit-Umsatz-Kurve ist bis 700 U/1 für 10 Minuten linear. Ein Aktivitätsanstieg durch Enzymverdünnung wurde nicht beobachtet. Mit der beschriebenen Meßanordnung wurde eine Nachweisgrenze von $0,9 \mathrm{U} / 1$ erreicht. Dies ist von besonderem Vorteil für den Nachweis der Creatinkinase-Isoenzyme nach chṛomatographischer Trennung. Der Variationskoeffizient der Präzision in der Serie lag bei 1,2\%. Die Präzision von Tag zu Tag hatte einen Variationskoeffizienten von 2,0\%. Die Testlösung ist für mindestens 24 Stunden haltbar.

\section{Introduction}

The determination of creatine kinase activity in serum is of great significance in the diagnosis of myocardial infarction and muscle disease. Striving for a high precision of the method and for reproducibility of the results the German Society for Clinical Chemistry 1970 and 1972 suggested the use of standàrd test conditions $(1,2)$. According to Oliver (3) and Rosalki (4) the reverse reaction (5), wàs chosen:

$\mathrm{ADP}+$ creatine phosphate $\underset{\mathrm{Mg}}{\stackrel{\text { creatine kinàse }}{\longrightarrow}} \mathrm{ATTP}+$ creatine

At the optimal $\mathrm{pH}$ value the formation of ATP and creatine from $A D P$ and creatine phosphate is about six times faster than the phosphorylation of creatine (6). The reaction rate is measured optically by reduction of NADP' ${ }^{+}$. During the enzymatic reaction creatine kinase is simultaneously reactivated by reduced glutathione (GSH). Results were calculated from the change in absorbance per minute after five minutes preincubation in the presence of the substrates. In spite of the methodological improvement some problems still remained:

1. The reactivator is unsuitable for the following reason: Glutathione may be partially present in the oxidized form (GSSG) which is a substrate for glutathione reductase (EC 1.6.4.2):

$\mathrm{NADPH}+\mathrm{H}^{+}+\mathrm{GSSG} \stackrel{\text { Glutathione reductase }}{\longrightarrow} \mathrm{NADP}{ }^{+}$ 
2. The change in absorbance during ten minutes was found to be linear only up to $200 \mathrm{U} / \mathrm{l}$ corresponding to four times the upper limit of the normal range.

3. Sera with higher activities have to be diluted. On the other hand there is no linear relationship between the amount of serum in the test and the measured reaction rate. Even activities of $100 \mathrm{U} / \mathrm{l}$ are found to be $10 \%$ too low compared with the assay result of a diluted specimen. Up to now this phenomenon has been interpreted by postulating the presence of serum inhibitors (8). Therefore Szasz et al. suggested dilution with inactivated serum (9).

4. In sera from patients with myocardial infarction myokinase (EC 2.7.4.3) is inhibited by AMP in the test solution (3). Unfortunately AMP also inhibits creatine kinase. An optimal balance between inhibition of myokinase and the unavoidable inhibition of creatine kinase was not achieved in the methods published.

\section{Materials and Methods}

\section{Specimens}

Following the proposal of the Expert Panel on Enzymes of the IFCC (10) we established the reproducibility of the method "with a clearly characterized human enzyme of the type found in serum ...". Therefore purified human isoenzyme creatine kinase-MM was used (product of Biochemical Research, E. Merck). Stock solution: Suspension of creatine kinase-MM in $650 \mathrm{~g} / \mathrm{l}$ ammonium sulfate stabilized with $10 \mathrm{~g} / \mathrm{l}$ globulin; activity: ca. $100 \mathrm{kU} / \mathrm{l}$. Before use the stock solution was diluted with $50 \mathrm{~g} / \mathrm{l}$ human serum albumin to an activity of about $100 \mathrm{U} / \mathrm{l}$. The sera used were taken from normal persons and patients with increased creatine kinase activities ranging from 50 to $1400 \mathrm{U} / \mathrm{l}$.

\section{Reagents}

For the preparation of the modified assay solutions all reagents were weighed out daily. Creatine phosphate, disodium salt; ADP, free acid; NADP, disodium salt; AMP, disodium salt; $\mathrm{N}$-acetyl cysteine; myokinase, porcine; hexokinase (EC 2.7.1.1.), from yeast; and glucose 6-phosphate dehydrogenase (EC 1.1.1.49), from yeast, were obtained from Boehringer Mannheim GmbH. Glucose; dithioerythritol; mercaptoethanol; magnesium acetate, and imidazole were obtained from $\mathrm{E}$. Merck. Dithiothreitol was obtained from Calbiochem. A commercial kit was used only to check the recommended test (2): CPK activated 124176 from Boehringer Mannheim.

Instrumentation and equipment

Photometer Eppendorf $1100 \mathrm{M}$ with logarithmic converter Eppendorf 1853; Chart recorder Eppendorf 4412. The temperature in the cuvette holder is regulated by a Colora Ultrathermostat NB 5.

\section{Measurement procedure}

Temperature: $\quad 25.0^{\circ} \mathrm{C} . \pm 0.05^{\circ} \mathrm{C}$

Wavelength: $\quad \mathrm{Hg}$ line $334 \mathrm{~nm}$

All measurements were made in duplicate. Each reaction rate was recorded individually for five minutes. Any instrumental drift was monitored and corrected by comparative absorbance measurements of diluted picric acid solution.

Attenuator range: Absorbance $0-0.250=20 \mathrm{~cm}$

Chart speed: $\quad 1 \mathrm{~cm} / \mathrm{min}$; in case of high activities with reaction rate lines steeper than $\operatorname{tg} \alpha=60^{\circ}$ speed was increased to $2 \mathrm{~cm} / \mathrm{min}$ or $5 \mathrm{~cm} / \mathrm{min}$.

Evaluation of results was done graphically by measuring the change of absorbance over a range of $10 \mathrm{~cm}$ on the chart. The corresponding time is then defined by the chosen chart speed.

\section{Results and Discussion}

\section{Buffer system and optimal $\mathrm{pH}$}

Triethanolamine- $\mathrm{HCl}$ is not suitable as a buffer system at a $\mathrm{pH}$ value of about 7.0 because if its high $\mathrm{pK}_{\mathrm{a}}$ value of 7.9. Imidazole/acetic acid was chosen as the buffer system according to Warren (11) and Forster et al. (6). A pH-optimum of 6.8 was found for the creatine kinase activity (Fig. 1). The same range was verified with pooled human serum.

\section{Inhibition of myokinase}

The influence of AMP concentration in the test was checked with regard to the inhibition of myokinase activity as well as to the inhibition of creatine kinase activity (Fig. 2). The test solution was identical for both the creatine kinase and myokinase measurements, except that in the latter case creatine phosphate was omitted. In the presence of $1 \mathrm{mmol} / \mathrm{l} \mathrm{ADP}$ the optimal concentration of AMP is about $5 \mathrm{mmol} / \mathrm{l}$ : inhibition of myokinase exceeds $90 \%$ whereas inhibition of creatine kinase is in the range of $5 \%$.

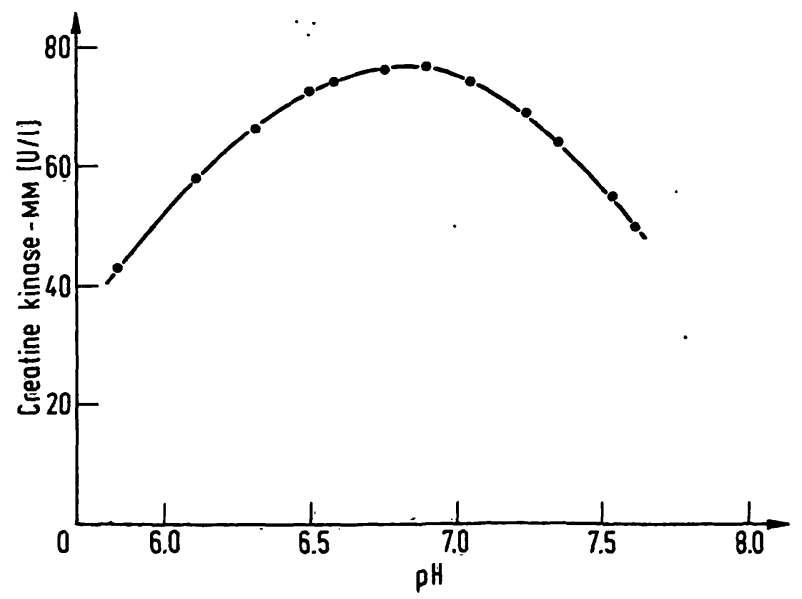

Fig. 1. Effect of the $\mathrm{pH}$ value in the assay solution on the activity of purified human creatine kinase-MM. Final concentrations in the assay solution: creatine phosphate $35 \mathrm{mmol} / \mathrm{l}$ glucose $20 \mathrm{mmol} / \mathrm{l}$; ADP $1 \mathrm{mmol} / 1$; NADP $0.6 \mathrm{mmol} / \mathrm{l}$; hexokinase $1.2 \mathrm{kU} / \mathrm{l}$; glucose 6-phosphate dehydrogenase $1.2 \mathrm{kU} / \mathrm{l}$; Mercaptoethanol $10 \mathrm{mmol} / \mathrm{l}$; magnesium acetate $10 \mathrm{mmol} / \mathrm{l}$; AMP $10 \mathrm{mmol} / 1$; imidazole/acetic acid buffer $100 \mathrm{mmol} / \mathrm{l}$. 


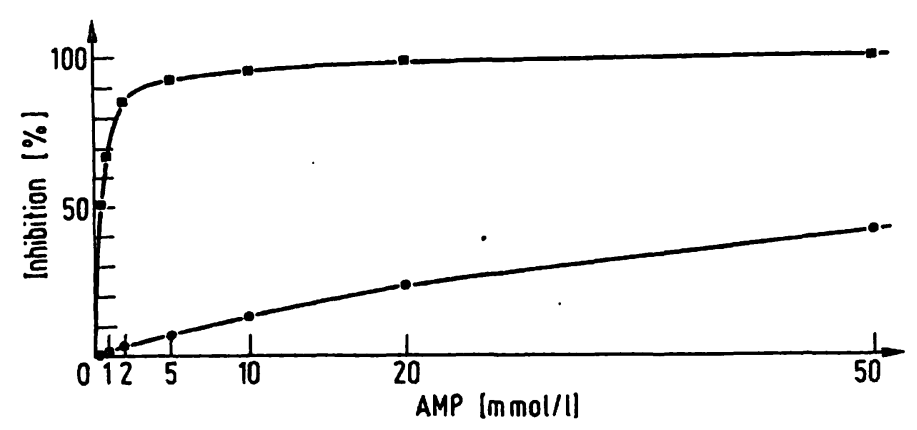

Fig. 2. Inhibition of creatine kinase-MM $(\bullet)$ and myokinase (a) depending on the AMP concentration. The other test conditions were the same as in Fig. 1.

\section{Blank reaction}

A blank reaction was found to be due to contaminants in the auxiliary enzymes. This blank reaction rate varied with the batch of the enzyme preparations, and had to be determined for each batch.

\section{Reactivation of creatine kinase}

The most suitable thiol compound for the reactivation of creatine kinase was evaluated by varying the reactivators in the test solution, and observing the reactivation potency for the different types of SHreagent (Tab. 1). Dithioerythritol and dithiothreitol proved to be the most effective.

In contrast to Warren (11) no significant difference between these two substances could be seen. The extent of reactivation was defined as per cent increase of activity due to the reactivator in relation to the activity without addition of a thiol compound. Necessarily the rate of reactivation is a function of the actual state of inactivation of the specimen. In spite of the augmented acitivity due to reactivation the true activity is not known precisely.

For further investigations dithioerythritol was chosen. Its isomer dithiothreitol is far less convenient, owing to

Tab. 1. Percentage increase of activity of purified human creatine kinase-MM by different SH-reagents (final concentration in the assay solution $10 \mathrm{mmol} / \mathrm{l})$. Other test conditions see Fig. 1 .

\begin{tabular}{llll}
\hline SH-reagent & U/1 & $\begin{array}{l}\text { increase } \\
(\mathrm{U} / 1)\end{array}$ & $\begin{array}{l}\text { increase } \\
(\%)\end{array}$ \\
\hline no activator & 152 & - & - \\
Dithioerythritol & 235 & 83 & 54 \\
Dithiothreitol & 233 & 81 & 53 \\
Mercaptoethanol & 228 & 76 & 50 \\
N-acetyl cysteine & 219 & 67 & 44 \\
\hline
\end{tabular}

its low melting point $\left(41^{\circ} \mathrm{C}\right)$ and its high hygroscopicity. Mercaptoethanol has such an unpleasant odor that it was not taken into consideration. $\mathrm{N}$-acetyl cysteine which is proposed by Forster et al. (6) is undoubtedly of advantage because of low price but shows far le:ss efficiency in regard to reactivation. In additional experiments the difference between dithioerythritol and $\mathrm{N}$-acetyl cysteine could be demonstrated even more impressively (Fig. 3): Serum was incubated with equimolar amounts of thiol reagent. The $\mathrm{pH}$ of the mixture was corrected to 6.8. After various preincubation intervals the mixture was assayed without additional thiol reagent. The results show that reactivation in serum is slower than in the assay solution. After about one hour serum reactivation with dithioerythritol exceeds reactivation in the assay. With $\mathrm{N}$-acetyl cysteine only $75 \%$ of the reactivation in the assay is obtained after $41 / 2$ hours of serum incubation. The decrease in activity after 15 minutes cannot be explained. The optimum concentration for dithioery. thritol proved to be $25 \mathrm{mmol} / \mathrm{l}$ (Fig. 4). As the reactivation of the enzyme may be influenced by the enzymatic reaction itself a preincubation period without substrate was used for reactivation. Moreover in this preincubation period no $\mathrm{NADP}^{+}$is consumed, so that in the same reaction time after starting higher activities could be measured without loss of linearity. A preincubation time of 10 minutes is sufficient. A longer time would be of little practical effect (Fig. 5).

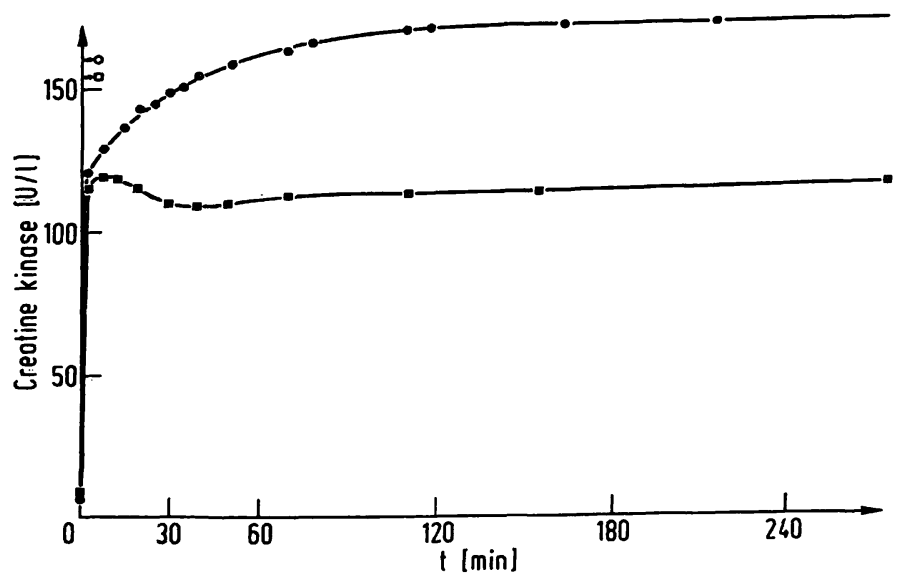

Fig. 3. Reactivation of serum. Serum was incubated with the thiol compound (final concentration $10 \mathrm{mmol} / \mathrm{l}, \mathrm{pH} 6.8$ ) for various periods. After the incubation the activity was assayed without further addition of SH-compound. A.MP $5 \mathrm{mmol} / \mathrm{liter}$; for other test conditions see Fig. 1.

- serum with dithioerythritol, no additional dithioerythritol in the assay solution,

- serum with $\mathrm{N}$-acetyl cysteine, no additional $\mathrm{N}$-acetyl cysteine in the assay solution,

$\longleftrightarrow$ dithioerythritol in the assay solution, no preincubation of serum

$\longleftrightarrow \mathrm{N}$-acetyl cysteine in the assay solution, no preincubation of serum. 


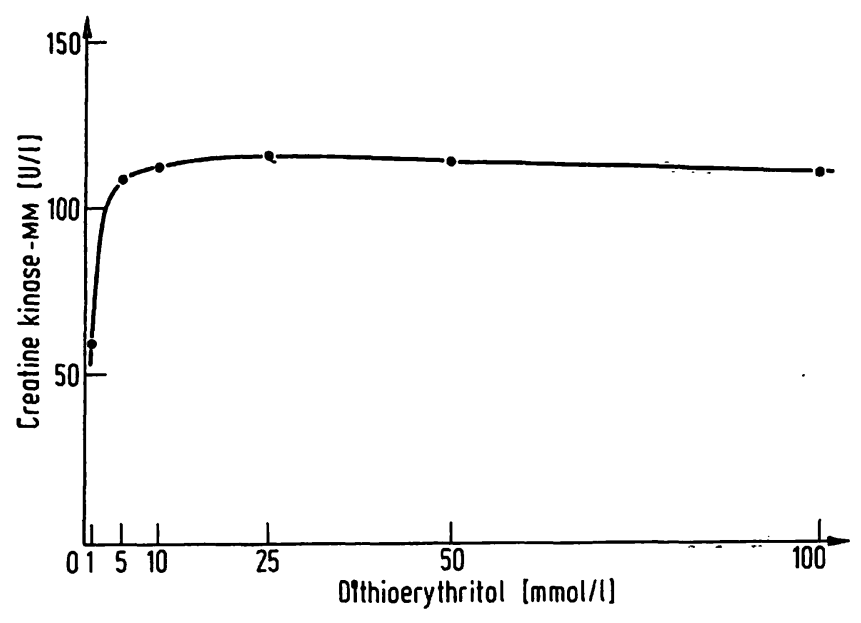

Fig. 4. Determination of the optimal dithioerythritol concentration. The other test conditions were the same as in Fig. 3.

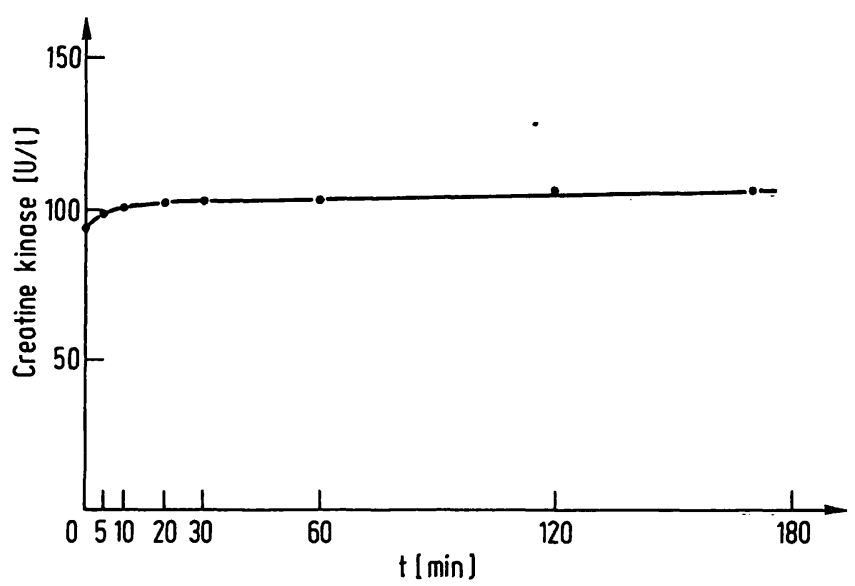

Fig. 5. Determination of the optimal preincubation time of creatine kinase in the assay solution. The enzyme reaction was started subsequently by adding creatine phosphate. Test conditions as in Fig. 3; dithioerythritol $25 \mathrm{mmol} / \mathrm{l}$.

\section{Suggested test procedure}

The measurement procedure is shown in Table 2. Final concentrations of the test solution are listed in Table 3. The concentration of $\mathrm{NADP}^{+}$was increased to diminish the competitive inhibition of the glucose 6-phosphate dehydrogenase by NADPH (12) when high creatine kinase activities were assayed. By separating the reactivation time from the enzyme reaction itself a low concentration of NADPH at the beginning of the reaction is achieved. In the method described here only about $12 \%$ of NADP ${ }^{+}$are reduced to NADPH when $700 \mathrm{U} / 1$ creatine kinase are assayed over a period of $10 \mathrm{~min}$. In the same case $64 \%$ of $\mathrm{NADP}^{+}$are consumed with the method mentioned at the beginning $(1,2)$. The activity of the auxiliary enzymes in combined optical tests has to be at least 100 -fold the activity of the enzyme to be assayed, otherwise the indicator system will be rate limiting (13). We therefore increased the activity of the auxiliary enzymes as shown in Table 3 . Thus a linear
Tab. 2. Analytical System.

\begin{tabular}{lr}
\hline Pipette & Volume \\
\hline 1 Buffer-Reagent Mixture & $2500 \mu \mathrm{l}$ \\
2 Auxiliary Enzyme Solution & $50 \mu \mathrm{l}$ \\
3 Serum (Sample) & $100 \mu \mathrm{l}$ \\
$\quad$ Incubate at $25.00^{\circ} \mathrm{C}$ for $10 \mathrm{~min}$ & \\
4 Creatine Phosphate Solution & $100 \mu \mathrm{l}$ \\
\hline
\end{tabular}

Mix well and record the changing absorbance at $334 \mathrm{~nm} \mathrm{Hg}$ for $5 \mathrm{~min}$. Calculate the average change in absorbance/min after blank correction.

Calculations

Catalytic concentration $=4450 \Delta \mathrm{A} / \mathrm{min}[\mathrm{U} / \mathrm{l}]$ where $\epsilon \mathrm{NADPH}_{334} \mathrm{~nm}, 25^{\circ} \mathrm{C}$ is $6.18\left[\mathrm{~cm}^{2} / \mu \mathrm{mol}\right]$ and the pathlength of the cuvette is $1 \mathrm{~cm}$.

Tab. 3. Final concentrations in the test solution.

\begin{tabular}{|c|c|c|}
\hline Buffer (pH 6.8) & Imidazole-Acetic Acid & $100 \mathrm{mmol} / \mathrm{l}$ \\
\hline Substrates & $\begin{array}{l}\text { Creatine Phosphate } \\
\text { Glucose }\end{array}$ & $\begin{array}{l}35 \mathrm{mmol} / \mathrm{l} \\
20 \mathrm{mmol} / \mathrm{l}\end{array}$ \\
\hline Coenzymes & $\begin{array}{l}\text { ADP } \\
\text { NADP } P^{+}\end{array}$ & $\begin{array}{l}1 \mathrm{mmol} / \mathrm{l} \\
2 \mathrm{mmol} / \mathrm{l}\end{array}$ \\
\hline Auxiliary Enzymes & $\begin{array}{l}\text { Hexokinase } \\
\text { Glucose 6-phosphate } \\
\text { dehydrogenase }\end{array}$ & $\begin{array}{l}3 \mathrm{kU} / \mathrm{l} \\
3 \mathrm{kU} / \mathrm{l}\end{array}$ \\
\hline $\begin{array}{l}\text { Creatine Kinase } \\
\text { Reactivator }\end{array}$ & Dithioerythritol & $25 \mathrm{mmol} / 1$ \\
\hline Activator & Magnesium Acetate & $10 \mathrm{mmol} / 1$ \\
\hline $\begin{array}{l}\text { Myokinase } \\
\text { Inhibitor }\end{array}$ & AMP & $5 \mathrm{mmol} / \mathrm{l}$ \\
\hline
\end{tabular}

proportionality up to $1400 \mathrm{U} / \mathrm{l}$ was found between the amount of enzyme in the test and the reaction rate (Fig. 6). The significance of a blank correction is also seen. The same range of linearity was found for sera with highly increased activities. Both graphs are nearly identical demonstrating good correspondence of creatine kinase-MM and sera.

The test solution is stable for at least one day at room temperature. From the analysis of regression between apparent loss of activity using a once prepared bufferreagent mixture and storage time (up to 10 days) of this mixture at room temperature the average decrease per day of activity due to aging of the test solution was $1.0 \%(y=-1.2 x+114.6, r=0.945)$.

\section{Quality control}

Quality control was performed with creatine kinaseMM in $50 \mathrm{~g} / 1$ human serum albumin and Precinorm-E. The within-run precision was $1.2 \% \mathrm{CV}$ with $\mathrm{n}=30$, 


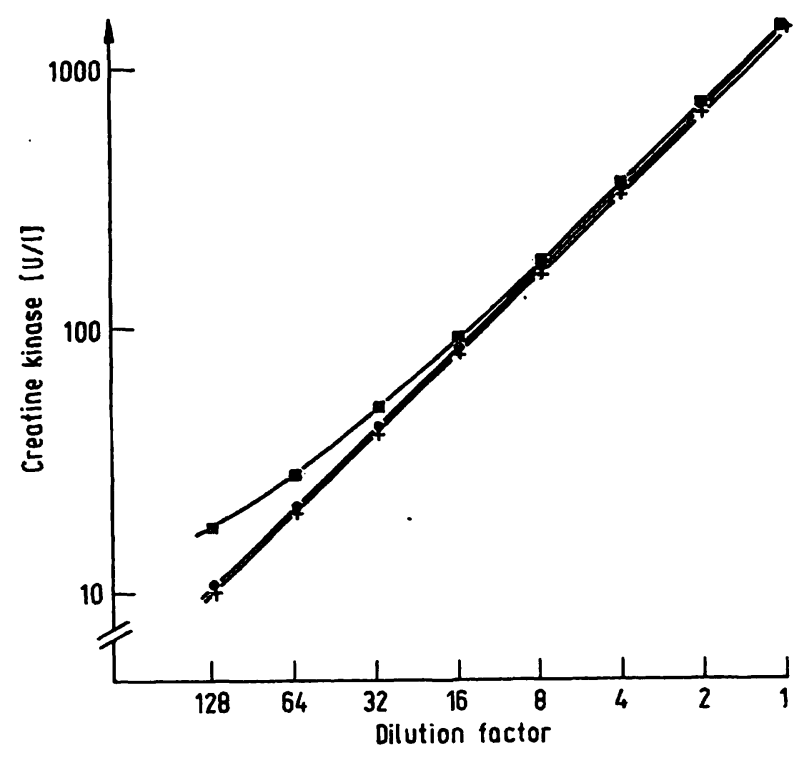

Fig. 6. Relationship between dilution of the specimen and measured activity. A double logarithmic scale was chosen for demonstrating clearly the linearity over the whole range from 10-1400 U/1. For test conditions see Table 3.

$\longrightarrow$ creatine kinase-MM, blank corrected, $1460 \mathrm{U} / 1$

- creatine kinase-MM, blank not corrected $X-X$ pool of 10 sera, blank corrected, $1400 \mathrm{U} / \mathrm{l}$.

$\overline{\mathrm{x}}=97.3 \mathrm{U} / \mathrm{l}$ and $\mathrm{s}=1.2 \mathrm{U} / \mathrm{l}$. The day-to-day precision was $2.0 \% \mathrm{CV}$ with $\mathrm{n}=20$ (the first of the duplicate values was taken), $\bar{x}=118.7 \mathrm{U} / 1$ and $s=2.4 \mathrm{U} / 1$. The sensitivity of detection was $0.9 \mathrm{U} / 1(\overline{\mathrm{x}}+3 \mathrm{~s}$ of "no enzyme" in $50 \mathrm{~g} / \mathrm{l}$ human serum albumin, $\mathrm{n}=20$, blank corrected).

\section{Comparison with established procedures}

The results were obtained by employing purified human creatine kinase-MM isoenzyme according to the published recommendations of the IFCC (10). The low activity of creatine kinase-MB which may be present in some sera does not impair the predominant role of creatine. kinase-MM. Serum was considered not to be suitable as a model specimen due to its individual composition and the possibility of interfering substances, e.g. drugs and their metabolites, the presence of which cannot be excluded. The validity of the test under optimized conditions was proved by a comparison with the method recommended by the German Society for Clinical Chemistry. Analysis of regression was carried out using 30 different sera with normal and elevated enzyme activities. Notwithstanding the objection to GSH as a reactivator and triethanolamine- $\mathrm{HCl}$ as a buffer system, the new assay clearly demonstrates increased sensitivity by detection of $75 \%$ higher activity in the same sera (Fig. 7), the coefficient of correlation being 0.987 .

A revised version of the recommended test (2) was suggested by Forster et al. in 1974 (6). N-acetyl cysteine is used as the reactivator and imidazole/acetic

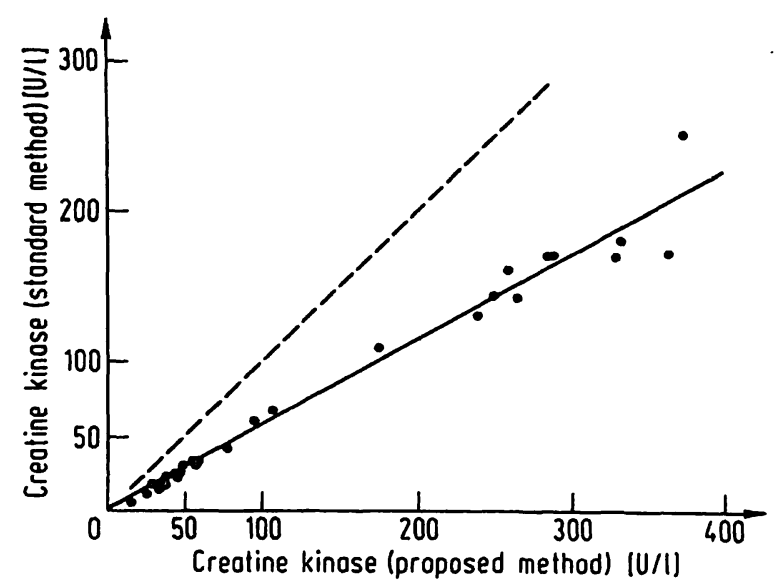

Fig. 7. Regression analysis: The proposed test (see Table 3) is compared with the standard method recommended by the German Society for Clinical Chemistry (2). $---y=x$ $-\quad y=0.57 x+3.1, \quad r=0.987$

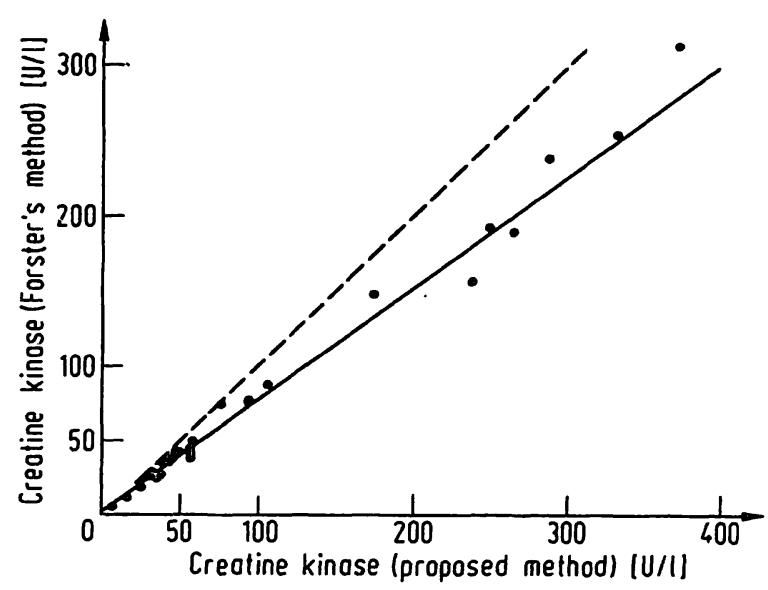

Fig. 8. Regression analysis: The proposed test (see Table 3) is compared with the method according to Forster et al. (6) $---y=x$

$y=0.75 x+3.6, \quad r=0.991$

acid is chosen as the buffer system. Analysis of regression with this test is shown in Figure 8. The coefficient of correlation here is 0.991 . Though the revised version is a clear improvement, the present method still determines $33 \%$ higher activities in the same samples. Two essential reasons account for this:

1. Dithioerythritol is more effective than $\mathrm{N}$-acetyl cysteine.

2. The preceding reactivation of creatine kinase before starting the enzyme reaction itself permits a higher reactivation rate of the enzyme before it is measured. Thus sensitivity is increased.

This is especially advantageous in the analysis of creatine kinase isoenzymes by chromatography when only low activities of creatine kinase-MB after myocardial infarction are present in serum. Hitherto, it was necessary for samples for the analysis of isoenzymes to have a significantly elevated activity, or they had to be concentrated (14). 


\section{References}

1. German Society for Clinical Chemistry (1970), this J. 8, 659-660.

2. German Society for Clinical Chemistry (1972), this J. 10, 281-291.

3. Oliver, I. T. (1955), Biochem. J. 61, 116-122.

4. Rosalki, S. B. (1967), J. Lab. Clin. Med. 69, 696-705.

5. Commission on Biochemical Nomenclature (1972), Enzyme Nomenclature, p. 15, Elsevier, Amsterdam.

6. Forster, G., Bernt, E., \& Bergmeyer, H. U. (1974), in Methods of Enzymatic Analysis (Bergmeyer, H. U., Ed.) 2nd ed. p. 784, Academic Press, New York and London.

7. Weidemann, G. (1973), this J. 11, 134-135.

8. Graig, F. A., Smith, I. C., \& Foldes, F. F. (1967), Clin. Chim. Acta 15, 107-111.
9. Szasz, G., Busch, E.-W., \& Farohs, H.-B. (1970), Deut. Med. Wochenschr. 95, 829-835.

10. Bowers, G. N. Jr., Bergmeyer, H. U., \& Moss, D. W. (1975), Clin. Chim. Acta 61, F 11-F 24. - This J. 13, $523-531$.

11. Warren, W. A. (1972), Clin. Chem. 18, 473-475.

12. Barman, T. E. (1969), Enzyme Hañdbook, Vol. 1 p. 73-74, Springer-Verlag, Berlin, Heidelberg, New York

13. Richterich, R. (1971), Klinische Chemie, 3rd. ed., p. 168, Verlag S. Karger, Basel.

14. Nealon, D. A., \& Henderson, A. R. (1975), Clin. Chem. $21,392=397$.
Prof. Dr. W. Rick

Institut für Klinische Chemie und Laboratoriumsdiagnostik Moorenstr. 5

D-4000 Düsseldorf 